\title{
A TELEPÜLÉSEK BELSŐ SZERKEZETÉNEK VIZSGÁLATA A LAKOSSÁG TÉRBELI ELOSZLÁSA ALAPJÁN
}

\author{
(A survey of the inner structure of the settlements by the spatial \\ distribution of population)
}

\section{KOCSIS ZSOLT}

\section{Bevezetés}

Győr, Szombathely és Veszprém összehasonlítása számos problémát vet fel. Vajon a hasonlóságok vagy a különbségek hangsúlyozása legyen-e a fontosabb. Most azonban másodlagos a kérdés, mert a belsỏ szerkezet feltárása a külön-külön is érdekes feladat, az azonosságok és az eltérések csak az összehasonlításban kapnak nagyobb szerepet. Az 1980. és 1990. évi népszámlálások számlálókörzetsoros adatainak számítógépes feldolgozása számos eredményt hozott, melyek részben módszertani jelentőségủek, részben a városok térszerkezetének feltárását tették lehetővé, természetesen az évtizednyi, rövid időtáv és a rendelkezésre álló népszámlálási adatok adta korlátok között.

Ezért a tanulmány egyfajta kísérletnek is számit, az alkalmazott módszer és a felhasznált adatok próbája, hogy a 2000. évi népszámlálás után három időpontra elvégezhetó legyen az újabb vizsgálat. Ez azért is ígérkezik nagyon érdekesnek, mert az 1980-as adatok még elég jól mutatják a szocialista rendszer uniformizáló hatását, az 1990-es adatokban már fellelhetök a nagyobb szabadságfok jelei, a panel lakótelepekkel szemben az egyéni lakásépítések térnyerését, míg a következö népszámlálás talán már egy majdnem teljesen piacgazdaságra épulő társadalom képét hozza.

\section{Kiinduló helyzet, felhasznált adatok}

A városszerkezet szempontjából fontos tényezök közül a domborzati-vízrajzi adottságok igen eltéröek. Győrben a nagy vízfolyások alapvetően meghatározzák a városképet, hiszen a forgalom számára komoly akadályt jelentenek. A nagy költségek miatt viszonylag kevés híd épưlt, ami az úthálózatot az átkelési pontokhoz koncentrálja.

Szombathely esetében a két kis patak nem befolyásolta döntó a városképet, a kis medrek nem hagytak mély nyomot az utcahálózatban.

Veszprémben a dombok jelentik a domináns elemet, a meredek kiemelkedések és a viszonylag mély, szűk völgyek határozottan kirajzolódnak a város térképén.

Természetesen a népesség maga és abszolút száma is alapvetỏ a városszerkezet kialakításában. Részben a lakosság által úzött foglalkozások, a különbözö gazdasági létesitmények, részben az egyéb társadalmi-gazdasági funkciók, a lakófunkció térigénye miatt. 
$\mathrm{Az}$ 1. ábra a modern népszámlálások adatai alapján mutatja be a városok népességfejlődését a jelenlegi közigazgatási határokra vonatkoztatva.

$$
\begin{gathered}
1 \text {. ÁBRA } \\
\text { A vizsgált városok népességszámának alakulása }
\end{gathered}
$$

(The number of population in the cities)

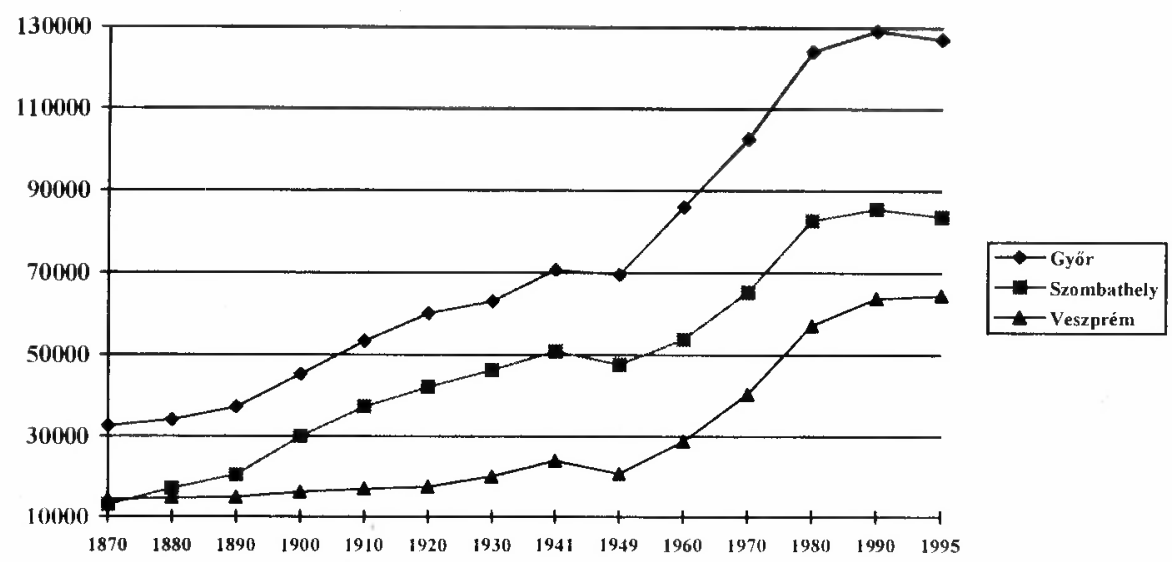

Forrás: KSH.

\section{TÁBLÁZAT}

A vizsgált városok néhány belterületi és külterületi adata (1995. január 1.)

(Some inner and outer city-area data of the cities)

\begin{tabular}{|l|c|c|c|}
\hline Megnevezés - város & Gyơr & Szombathely & Veszprém \\
\hline Főldterület (ha) & 17479 & 9752 & 12693 \\
\hline Lakónépesség (fö) & 127236 & 83694 & 64622 \\
\hline A központi belterullet lakónépessége (fö) & 114188 & 84657 & 59792 \\
\hline Az 1970 után csatolt falvak lakónépessége (fö) & 14754 & 873 & 3534 \\
\hline Központi belterület aránya a lakónépességböl (\%) & $\mathbf{8 8 , 2 8}$ & 98,87 & 93,62 \\
\hline
\end{tabular}

\section{Forrás: KSH.}

Látható, hogy a három város népessége közel sem egyenlő. Kisebb településeken a területhasznosítás is egyhangúbb lehet, a különböző övezetek, zónák kevésbé hangsúlyosak, vagy egyáltalán nem alakulnak ki. Mivel magyar viszonylatban még Veszprém népessége is nagynak számít, ezért megfelelően kis alapegységet választva elegendően finom tagolását adhatjuk a város szerkezetének.

Mivel a statisztikai adatok háztartásonkénti, személyenkénti adatai nem hozzáférhetők, de nem is lehetne feldolgozni azokat (elsösorban a térképi ábrázolás lenne költséges, problematikus, többek között a térben egymás fölött elhelyezkedő személyek, lakások miatt), ezért kézenfekvő a 150-350 föt magukba foglaló számlálókörzetek használata.

Sajnos, a számlálókörzetek beosztása nem teszi lehetóvé korábbi adatok felhasználását, ami azért is gondot okoz, mert tíz év igen kis idö, ezért a városokban lezajlott társadalmi folyamatok dinamikája csak nehezen adható vissza. Ez a kijelentések értékéböl is sokat 
elvesz, hiszen nehezen igazolható, hogy pl. tendenciáról van szó, nem pedig véletlen, rövid életủ folyamatról. Az 1980-1990-es népszámlálások rendelkeznek az összehasonlítást lehetỏvé tevỏ azonos területi vonatkoztatással, a korábbi népszámlálások nem, viszont a 2000 . évi az utolsó kettő bázisán zajlik majd, ezért adataik összevethetỏk lesznek a térben is.

A rendelkezésre álló adatok eltérő struktúrája miatt csak huszonhat mutató került felhasználásra, ezek azonban már mindkét időpontra majdnem teljesen azonos körzetbeosztással kerültek felvételre, tehát az összehasonításra alkalmasak.

A huszonhat mutatóból négy a népesség korszerkezetét irja le, egy az iskolázottságát, hat a foglalkozási struktúrát, illetve az aktivitást. Végül tizenöt a lakásállomány infrastrukturális felszereltségét, a lakások korát, a házak lakás- és emeletszámát, a lakásellátottságot (pl. egy lakásra jutó lakó, család, háztartás, a családok, háztartások nagysága, stb.) mutatja be.

Az adatok ábrázolása Mapinfo szoftver segitségével a városok digitalizált térképén, számlálókörzetsorosan történt. Ez nagyban megkönnyítette a feldolgozás, kiértékelést, de a kijelentések alátámasztására, illusztrálására is kiválóan alkalmas.

A térképek a kereskedelemben beszerezhető várostérképek erősen csökkentett tartalmának digitalizálásával készültek, majd új rétegként felkerült a számlálókörzetek határa is.

A népszámlálási körzetek használata igen nagy előny a korábbi városszerkezeti, elsősorban morfológiai vizsgálatokkal szemben, ahol a hagyományos kézi rajzolás adta lehetóségek miatt általában városrendezési körzetek szintjén készülttek a feldolgozások és az ábrák is.

Ugyancsak komoly előny volt a nagy merítés, hiszen a szükségból kihagyott számlálókörzetek (intézményi háztartások - kollégiumok, gyermek- és nyugdíjas otthonok, munkásszállások, stb., illetve a külterületek - gátőrházak, kisebb mezőgazdasági jellegủ telepek, üzemek, stb.) nélkül is általában a városok népességének 95\%-a a vizsgálat tárgyát és alanyát képezte.

A külterületek a dunántúli városoknál hagyományosan kis százalékát jelentik a városi népességnek, ráadásul teljesen torz kor- és foglalkozási struktúrájuk az adatok feldolgozásánál hasonló problémákat jelentett volna, mint az intézményi háztartásoké. Kétségtelen, hogy ezek is város részét képezik, de a feldolgozás során olyan mennyiségú többlet munkát eredményeztek volna, amelynek eredmény-oldalon nincs meg a megfelelő haszna.

A számlálókörzetek egyébként sok kellemetlenséget okoztak, ami arra vezethetô vissza, hogy a Központi Statisztikai Hivatal a saját maga számára gyújti az adatokat elsősorban, a szervezeten kívuili felhasználók igényei alig játszanak szerepet az adatbázisok struktúrájának kialakításában. Igaz ez mind a vonatkoztatási alap, mind a felvett mutatók esetében.

A számlálókörzetek határai ugyanis túlságosan nagy ingadozást mutatnak, lehatárolásuk gyakran önkényes. A kutatható térszerkezet legkisebb elemeiként több figyelmet érdemelnének. Szükségszerủ módosulásuk (építkezések, bontások) nem okoz problémát, ennyi pontatlanságot a vizsgálat még elbírna, de a térképi ábrázolásuk nehézkes. A kis népesség miatt a panelházak néhány lépcsőháza kitesz egy-egy körzetet, ezek pedig alig láthatók a város térképén.

Máskor viszont hatalmas, városrész nagyságú számlálókörzetek is vannak, amelyek a tematikus ábrázolásokon hatalmas, egybefuggő foltként jelennek meg. Azt a látszatot 
keltik, hogy a város jelentékeny részét képezik az éppen bemutatott szempontból, miközben egyetlèn számlálókörzetként arányuk az össznépességen belül általában ezrelékes nagyságrendú.

Ez a probléma vetette fel az adatok intenzitás szerinti vonalkázással való bemutatásának korlátait. Más módszer azonban nem adódott, mert a pontokkal történó ábrázolás a számlálókörzetek igen nagy területbeli szórása miatt ugyanúgy torzította a képet, a színes ábrázolás pedig a sokszorositás, a publikálás során okozott volna gondokat, ráadásul az eredmény ott sem lett volna sokkal korrektebb.

Mindezek ellenére a számlálókörzetsoros adatok feldolgozása és bemutatása sokkal jobb eredményt adhat, mint a kérdöíves, viszonylag kis mintára támaszkodó felmérés. Igaz, az adatok nem frissek, nincs mód egyéni válaszok adására, de mivel majdnem teljes merítést jelentenek, a levont következtetések megalapozottak.

\section{Eredmények}

A munka abból a feltételezésböl indult ki, hogy a lakóhely, lakókörnyezet befolyásolja, alakítja az embert, az viszont szintén átalakithatja lakókörnyezetét. Egy település életében nem közömbös, hogy a népesség (összesen vagy városrészenként értelmezve) rendelkezike azokkal a képességekkel, lehetöségekkel, amelyek pozitív irányú átalakítást tesznek lehetővé. Más esetben pedig jövedelmi szintje, társadalmi helyzete, kora, stb. okán akarvaakaratlanul is a leromlás felé mozdítja el lakókörnyezetét, annak infrastruktúráját, épületállományát lelakva a városrész megítélését, presztízsét, ezáltal az ott élök megitélését is rontva, tovább rontva.

Ugyancsak meghatározó, hogy a város tud-e olyan területeket kínálni, amelyek megfelelő feltételeket nyújtanak a társadalmi élettevékenységek, a munka, a pihenés, stb. számára. Amennyiben nem, akkor az aktívak, a társadalmilag, anyagilag mobil lakosok elhagyják a várost.

Ezért is fontos a lakosság térbeliségének kutatása, mert települések társadalmi térszerkezete (foglalkozási-, korstruktúra, stb.) a lakásmutatókkal kiegészítve nagyon jól jelzi az adott városrészek pillanatnyi helyzetét, lehetőségeit. A település belsö terében zajló átrendeződési folyamatokat ismerve időben be lehet avatkozni, hogy egy-egy lakónegyedet megmentsenek a pusztulástól, hogy egy-egy elesett társadalmi rétegnek jobb lakókörnyezetet teremtve mentöövet dobjanak.

A feltevés egyik fele inkább a szociológia tárgykörébe tartozik: a városi térben elfoglalt hely részben tükrözi a társadalmi helyzetet, részben okozója, részben következménye annak. A lakosokra gyakorolt átalakító hatása jelen kutatás módszereivel, eszközeivel közvetlenül nem igazolható.

Közvetve érvényesül, amennyiben az uniformizált panel lakótelepeken 1990-re a lakosok foglalkozási- és korszerkezete is egyöntetúbb lett, mint 1980-ban volt. Mivel kevés változatosságot kínál a panel, lakói részben elszürkülnek, részben kicserélődnek, olyanok költöznek be, akiknek meg kell elégedniük a körülményekkel.

A másik felét sokkal jobban alátámasztják az adatok: az ember átalakítja lakókörnyezetét, a teret, amelyben lakik.

A térinformatikai rendszerben történö ábrázolás segitségével jól nyomon követhetők a városi téren belüli mozgások. Ezekböl arra lehet következtetni, hogy a vizsgált időpontban az egyéb ágakban tevékenykedő, általában idősebb aktív korú lakosok, a jobb 
lakásköruilményekből ítélve magasabb jövedelemmel rendelkezők bizonyos koncentrálódása a kertvárosias, többnyire a csatolt falvak területén található lakókörzetekben nem véletlen.

Mivel a korábbi időponthoz képest jelentősen csökkent a belső területek abszolút túlsúlya, a lakótelepek magas részesedése az ilyen adatokkal jellemezhetó lakosok körében, a csatolt falvak esetében nem csupán a városi átlagba simuló elmozdulásról van szó.

A korábban egyértelmúen falusias jellegũ városrészek, a csatolt falvak (szub)urbanizálódása, az infrastruktúra bizonyos elemeinek városias szintre emelkedése, a lakosság kor- és foglalkozási szerkezetének városiasodása nem oka a magasabb státuszú rétegek kiköltözésének, hanem következménye.

Az idősebb falurészeken fennmaradó alacsonyabb színvonalú lakásállomány, az öregebb korszerkezet, az ipari és mezógazdasági foglalkoztatottak viszonylagos magas aránya megmaradt. Az új utcákból álló falurészekben viszont városias népesség foglalkozási szerkezete (egyéb és szellemi keresők túlsúlya), a laksủrủség magasabb (kisebb kertek, több szintes házak, stb.), jobb a lakások felszereltsége, magasabb a szobaszáma.

A város belső területéról kiköltözők városiassá formálják új lakóhelyüket, míg a hagyományos, elsősorban építészeti értelemben vett városias (magas házak, nagy laksűrüség) panel lakótelepek népessége a falvakéhoz kezd hasonlítani.

A települések szerkezete általában négy övezetre osztható. A legbelsỏ történelmi mag megórizte centrumszerepét, lakófunkciói feléledöben vannak, lakásállománya fokozatosan jovul, lakókörnyezetként presztízse gyorsan emelkedik.

A második övezet a kisvárosias, néha kertvárosias, villanegyed szerũ városrészek övezete. Ezekben terjednek a belvárosból kiszoruló különbỏzö gazdasági tevékenységek. A lakások nagyobb alapterületủek (általában régi polgárházakról van szó), ezért kisebb vállalkozásokat képesek befogadni.

A harmadik övezet a lakótelepeké. Itt a lakosság korösszetétele változatos, de foglalkozási szerkezete az ipar és az egyéb ágak által meghatározott. A lakótelepek elsó ütemei elöregedőben vannak, a legkésőbb épített tömbökben még sok fiatal, gyermek él.

A negyedik övezet az utóbbi évtizedekben a városokhoz csatolt falvak területe. Itt egyöntetúen a népesség fiatalodása, a lakások korának és minőségének, nagyságának emelkedése figyelhetỏ meg. A foglalkozási szerkezet alapján városiasnak nevezhetó területekról van szó.

A településen belüli térben elmozduló népesség a városrészeket is elmozdítja egy minóségi skálán. A magasabb jövedelmü rétegek beköltözése megemeli a városrészek presztízsét, az alacsony jövedelmüeké csökkenti. Ennek megfelelöen a városon belül pl. az elit negyed is vándorlásba kezd. A belvárosok korábbi elhanyagolása után a hagyományos kertvárosok, majd az utolsó évtizedben a csatolt falvak területére került. 1990-ben Veszprémben és Győrben is kimutathatóan ez a mozgás részben ismét a régi városmag felé irányul.

Szombathelyen a belváros sosem vesztette el presztízsét, a két háború között épült, jó minöségü lakásállományának köszönhetően meg tudta örizni lakófunkcióit és az állami nagyberuházások, lakásépítések is megkímélték. Ezért a városmagot viszonylag ritkán csúfítják el modern, a környezetbe nem illó épületek, ugyanakkor felújítása sem olyan kampányszerúen történt, történik, mint Veszprémben és Győrben az óvárosoké. 
Mivel a belváros nem szorult komolyabb rehabilitációra, ezért a tehetősebbek kiáramlása nem volt jelentős az elmúlt évtizedekben, ugyanakkor a visszaáramlás sem lehet olyan markáns, mint a másik két város esetében.

A sürủ beépítettség miatt azonban nem is lehet a magasabb jövedelmüek beköltözésének célpontja, azok inkább a csónakázó tó körüli, zöldterülettel bỏvelkedó területeket preferálják.

A mozgások irányultságában felfedezhető különbségek okai sokrétủek. Jelen kutatás nem is tudja ezeket feltárni, de még a lehetséges tényezők felsorolása is meghaladhatná e tanulmány kereteit.

Minden esetre megemlítendő a természeti tényezók és a történelem által befolyásolva kialakult és fennmaradt régi városszerkezet eltérö fontossága. (Györben kifejezetten nagy kiterjedésü a történelminek tekinthető városmag, Veszprémben sokkal kisebb volt, ráadásul nagy részét elpusztították az elmúlt évtizedek épitkezései. Szombathelyen pedig tulajdonképpen csak a közintézmények nagyobb épületei jelentik a történelmet, a lakóházak között igen kevés a komoly értéket képviselő múemlék, így a történelmi mag néhány utcányi.)

Ugyancsak fontos a helyi és az országos politika szerepe. Közismert a megyeszékhelyek közötti rivalizálásnak pl. a toronyházak építésében is megnyilvánuló hatása, de napjainkban is határozottan irányithatja a város a térszerkezetet formáló folyamatokat, hiszen a különbözö beépitési lehetőségek felkínálása, a városi telekpolitika, a rendeletek útján más és más irányba lehet terelni lakásépítéseket, a városon belüli mozgásokat.

Végül megfelelő adatok és információk hiányában csak utalni lehet a helyi társadalom, illetve a helyi gazdaság, azok résztvevőinek vásárlóerejére is.

A vizsgálat azt is bizonyította, hogy a számlálókörzetekböl felépülő városrendezési körzetek, a tradicionális városrészek nem alkotnak összefüggő, egységes területeket. Túl nagy megfigyelési egységek ahhoz, hogy egy város társadalmának térszerkezetét bemutathassák.

A települések morfológiai elemzése is csak ezen a kiindulási egységen alapulhat, mert kisebb városokban egy-egy lakónegyed túl nagy területet jelenthet. Egymástól élesen elkülönülő lakókörnyezetek is eltủnhetnek egy szürke, semmit mondó városrendezési körzet átlaga mögött.

$\mathrm{Az}$ adatok sokváltozós elemzése viszonylag objektiv, a kutató által végzett paraméterezést sem torzitja jelentősen a képet. Későbbi időpontban újra lefolytatható, a vizsgálat más telepưlésekre is elvégezhető, ezért különösen alkalmas összehasonlító kutatások végzésére. Megfelelö számitástechnikai háttérrel olcsó és gyors módszer egy adott település, vagy több település összehasonlító városszerkezeti kutatására.

A földrajzi információs rendszerek ugyan először a természeti földrajzban kerültek alkalmazásra, de a társadalomföldrajz is jól tudja hasznosítani ezeket. Nem csak a tematikus térképek elóállításával szolgálhatja a kutatást egy földrajzi információs rendszer, hiszen megfelelő adatokkal feltöltve különbözö városi térfolyamatok modellezését, a várostervezést, fejlesztést is lehetővé teszi, segíti. Az adatok feldolgozása terén olyan hatékony eszközt jelent, amely jelentősen meggyorsítja az eredmények elkészültét és így közlését is.

$\mathrm{Az}$ adatok bemutatásával pedig korábban szinte elérhetetlen pontossággal és gyorsasággal lehet a városszerkezet különbözö elemeit bemutatni, hiszen pl. a kis területủ számlálókörzetek egy hagyományos technikával készült tusrajzon nem is voltak bemutathatók. 
A városok vizsgálata digitalizált térképek segítségével, térinformatikai keretek között történt. Tulajdonképpen egy modell került megalkotásra, hogyan lehet a várost érintö problémákat térbeli egységekhez kapcsolódó adatok formájában megfogni, vizsgálni, késöbb kezelni.

Megfeleló érdeklődés mellett, komolyabb eszkőzigénnyel szinte korlátlan a felhasználási lehetőség. A demográfiai hangsúlyú elemzés is nagyon jó szolgálatot tehet városi szintú stratégiai döntések meghozatalánál. Akár számlálókörzet szintủ népesség-prognózis alapját is képezheti, vagy egy fájdalmasan aktuális példaként említhető alkalmazási terület: néhány évre elöre tervezni lehet, melyik városrészben hány iskolát kell bezárni tanulók hiányában.

Ugyancsak alkalmas a rendszer telekhatáros térképekre alapozva az ingatlanárakkal feltöltve azok alakulásának modellezésére, elörejelzésére.

A társadalmi mozgások figyelésével megelőzhető egész városrészek lepusztulása. Megfelelő beavatkozással az elöregedés, az épületállomány leromlása megelözhetö, ezáltal az ott lakók számára jobb minőségú lakókörnyezet, jobb élet és ezáltal jobb kilátások, szebb jövö biztosítható.

\section{Irodalom}

Becsei J. (1986) Településen belüli társadalom és morfológia. Alföldi Tanulmányok XII. 80-97. o.

Berényi I. (1992) Az alkalmazott szocialgeográfia elméleti és módszertani kérdései. Földrajzi Tanulmányok 22. Budapest.

Faßmann, H. (1991) Faktorökológia - kutatási koncepció zsákutcában? Tér és Társadalom 1. 73-85. o.

F. Kovács E. (1991) Városok sokváltozós térben. Budapest.

Kárpáti Z. (1991) Városszerkezet és a polgárosodás esélyei. Kutatási beszámoló, Kézirat. Budapest.

Kocsis Zs. (1990) Gyốr regionális térszenvezö funkcióinak néhány elemének vizsgálata térben és idöben. Kézirat, egyetemi szakdolgozat, Györ, 66. o.

Kocsis Zs. (1992) A faktor-és klaszteranalizis alkalmazási lehetốségei a városszerkezet kutatásában Gyär példájón. Kézirat, egyetemi doktori disszertáció, Halimba, 203. o.

Kocsis Zs. (1993) Three phases of urbanization of Gyôr. Architektura a Urbanizacia, megjelenés alatt, Bratislava.

Kocsis Zs. (1994) The historical and recent problems of suburbanization in Gyôr. In: Seconde Conference International d' Histoire Urbaine, Strassbourg, 1-7. o.

Konrád Gy. - Szelényi I. (1989) Az értelmiség útja az osztályhatalomhoz. Budapest.

Központi Statisztikai Hivatal és megyei igazgatóságainak kiadványai:

Az.1980. És 1990. évi népszámlálás adatai. Külterületi és számlálókörzetsoros adatok. Györ-Sopron, Vas és Veszprém megyék kötetei.

Az 1990. évi népszámlálás adatai. CD-ROM sorozat 3. sz. Budapest.

Györ-Moson-Sopron, Vas és Veszprém megyék statisztikai évkőnyvei. Györ, Szombathely, Veszprém.

Lichtenberger, E. (1987) Stadtentwicklung und dynamische Faktorialökologie. Wien.

Szelényi I. (1990) Városi társadalmi egyenlôtlenségek. Budapest.

Tózsa I. (1995) Budapest zöldterületeinek földrajzi vizsgálata. Földrajzi Értesitổ 3-4. sz. 193-212. o. 


\section{Abstract}

The study started from the concept that the place of residence, the residential environment shape and influence people who, in return, can also transform their residential environment. It is not indifferent in the life of a settlement whether its population is endowed or not with the skills and possibilities which enable transitions of a positive direction. In other cases, because of their income level, social position, age etc., they cannot help bringing their residential environment towards deterioration, running down infrastructure and buildings, thus worsening, further worsening the judgement and prestige of certain parts of the towns and this way also of those who live there.

It is also decisive if a town can provide or not areas offering acceptable conditions for social activities, work, recreation etc. If not, the active, socially and financially mobile citizens will leave the town.

Among other things, that is why researches on the spatial characteristics of population are important: The social spatial structure of the individual settlements, supplemented with housing indices, are very good indicators of the present situation and opportunities of certain parts of the towns. Knowing the rearrangement processes in the inner space of the settlements, intervention may come in time in order to save some blocks from deterioration and give some handicapped social layers a last chance by creating a better residential environment.

Half of the concept is of rather sociological nature: The place occupied in the urban space partly reflects, partly causes and partly is the result of the social position. Its population-transforming effects indirectly work, as in the uniform block of flats the occupational and age structure of the population became much more homogeneous by 1990 than it was in 1980. As the panel flats offer little versatility, their population partly becomes apathetic, partly is exchanged and those move in who have to make do with the existing conditions. The other half is much better supported by data: Human beings transform their residential environment, the space in which they live. 